\title{
Analiza symulacyjna wpływu wybranych parametrów hamulca pneumatycznego na skuteczność jego dzialania
}

\author{
$W$ artykule przedstawiono skrótowo metodę modelowania uktadu pneumatycznego hamulca \\ pociagu, określania drogi hamowania i sit wzdlużnych w modelu pociagu sztywnego. Wyko- \\ rzystujac przedstawionq metodę modelowania dokonano analizy wpływu parametrów pneu- \\ matycznego układu hamulcowego na skuteczność jego działania. Przeanalizowano różne \\ możliwe lub hipotetyczne zmiany parametrów uktadu, stosujac celowo uproszczony uktad \\ cierny w celu uwypuklenia wyników zmian układu pneumatycznego.
}

\section{Wstęp}

Układ hamulcowy pociagu jest jednym z najważniejszych systemów pojazdów szynowych zapewniających bezpieczeństwo ruchu łącznie $z$ bezpieczeństwem ludzkim. Istnieją różne rodzaje hamulca kolejowego. Wyróżnia się na tym tle współczesny pneumatyczny hamulec cierny, który mimo wad posiada niezaprzeczalne zalety i zapewnia duże bezpieczeństwo działania, także w sytuacjach nadzwyczajnych (np. zerwanie składu pociagu i odłączenie od sterowania i zasilania).

Na Politechnice Poznańskiej opracowano metode pozwalająca na symulację działania całego układu hamulca pneumatycznego różnorodnej budowy, przedstawioną w kilku publikacjach $[1,2,3,7,8,9$, 10,12 i 13]. Samych programów symulacyjnych napisanych w FORTRANIE nie publikowano. Dla uściślenia metody symulacyjnej dokonano weryfikacji modeli i identyfikacji parametrów matematycznych modeli układu hamulcowego. Dokonano tego na podstawie badań przeprowadzonych na własnym stanowisku badawczym i w oparciu o wyniki pomiarów obcych, co częściowo omówiono w [11].

Celem niniejszej publikacji jest przedstawienie możliwości wykorzystania metody symulacyjnej do analizy wpływu podstawowych parametrów układu hamulcowego na przebieg hamowania, drogi hamowania i wartości maksymalnych sił wzdłużnych w modelu pociaggu sztywnego. Starano się, by analizy, pomimo że oparte na konkretnych symulacjach, nosiły miano uogólnionych. Dlatego zastosowano uproszczone modelowanie współczynnika tarcia, brak oporów ruchu i umiarkowaną intensywność hamowania; pomimo założonej ogólności rozważań, analizy są oparte o układy rzeczywiste.

\section{Matematyczne modelowanie elementów ukła- du przewodu głównego}

Ze względu na warunki pracy układu hamulcowego, interesujące są zachodzące w nim procesy przejściowe. Przepływ powietrza w przewodzie głównym

(PG) charakteryzuje się intensywnym występowaniem (silnie wythumianych) zjawisk falowych i przepływami ze znacznymi spadkami ciśnień wywołanych oporami przepływu wzdłuż przewodu. Opisywany jest on układem równań różniczkowych, w których uwzględniono niestacjonarne przepływy płynu ściśliwego. Przewód główny posiada niewielką średnicę w porównaniu $\mathrm{z}$ jego długością, a najbardziej interesujący jest przebieg ciśnienia powietrza występujący na jego długości. Można uznać, że rozkłady prędkości powietrza wzdłuż promienia przewodu są nieistotne, a przez prędkość przepływu rozumie się dalej średnią prędkość w przekroju rurociagu. Analizy matematyczne przepływu gazu w PG opisane są układem nieliniowych równań różniczkowych cząstkowych jednowymiarowych. W [2] przedstawiono wcześniejszą ich wersję, a w [3 i 13] uściślona, $m$. in. przez użycie funkcji delta Diraca do opisu dopływających do przewodu głównego dyskretnych po długości PG strumieni powietrza.

Straty przepływu powietrza przewodu można podzielić na straty: tarcia o ścianki i miejscowe zmian kształtu [13].

Straty tarcia powietrza o ścianki przewodu opisane współczynnikiem oporu $\lambda$ są zależne od względnej wysokości nierówności powierzchni rury i od liczby Reynoldsa; są zmienne na długości przewodu i w czasie procesu i zostały dokładniej omówione w [2].

Przewód główny zbudowany jest $\mathrm{z}$ rury stalowej walcowanej. Dla takiego tworzywa bezwzględna chropowatość rury nowej wg [14] wynosi $\mathrm{k}=0,02 \div$ $0,1 \mathrm{~mm}$, co daje wartość względnej chropowatości rury dla pociagu towarowego ok. $0.0006 \div 0,003$. Według [14] dla takiego tworzywa zastosować można uśrednione wartości nierówności i zależności Colenbooka-White'a, dobrze odwzorowujące wartości oporów dla rur komercyjnych.

Rury stalowe tworzące przewód główny nie są pokrywane od wewnątrz antykorozyjnie i pomimo stoso- 
wania odwadniaczy pokrywają się niewielką korozją. Powoduje to nieokreślony wzrost wysokości nierówności, zależny również od czasu eksploatacji przewodu. Szczegółowe rozpatrzenie oporów zawarto w [13].

Modelowania odgałęzień PG dokonano dwoma sposobami. Metoda dokładniejsza polega na przyjęciu w modelu przewodu głównego każdego odgałęzienia jako odcinka przewodu o zmiennym na jego długości stanie gazu; odcinki te opisane są MES uwzględniającą również zjawiska falowe. Metoda przybliżona opisuje odgałęzienia przewodu współczynnikiem objętości dodatkowych. Został on wprowadzony przez autora $i$ jest bardzo wygodnym elementem modelowania PG. Różne sposoby opisu odgałęzień przedstawiono $\mathrm{w}$ [2 i 13$]$.

Przenikanie ciepła z powietrza zawartego w układzie hamulcowym do obudowy układu hamulcowego i do otoczenia ma duży wpływ na przebieg procesów pneumatycznych. Brak jest w układzie elementów izolacji cieplnej. W przewodzie głównym duża część energii przepływu gazu jest dławiona i zamieniana na ciepło. Rozchodzenie się fali hamowania jest zbliżone do adiabatycznego, natomiast w przewodzie głównym po kilku sekundach, a w zbiornikach układu po kilkudziesięciu sekundach temperatura wyrównuje się do temperatury otoczenia, a przemiana gazu zbliża się do izotermicznej. Zjawisko jest więc skomplikowane. Również dysze zabudowane w układzie pneumatycznym służące do znaczącego zdławienia przepływu charakteryzują się znacznymi stratami energii przepływu, zamienianymi na ciepło.

Zmiany temperatury gazu $\mathrm{w}$ układzie hamulcowym mogą chwilowo osiagnąc kilkadziesiąt stopni Celsjusza. Wymiana ciepła powietrza w układzie hamulcowym $z$ otoczeniem może wywołać różnorodne zjawiska wymienione w [1, 2 i 13], głównie zmniejszenie prędkości rozchodzenia się i rozmycie fali hamowania o większych amplitudach i niejednoznaczne zmiany ciśnienia $\mathrm{w}$ pojemnościach i cylindrach hamulcowych (z powodu wolnego wyrównywania się temperatur następuje dalsza zmiana ciśnień $\mathrm{z}$ różnymi konsekwencjami w zależności od budowy sterowania).

Aparaty hamulcowe, takie jak zawór maszynisty, zawory rozrządcze $\mathrm{z}$ kompletem zbiorników i urządzenia realizujące siłę hamowania (głównie cylindry hamulcowe) zamodelowano jako zbiory elementów składowych punktowych bez rozpatrywania fal zmian ciśnienia na długości elementu. Ich działanie opisano równaniami mechaniki płynów i termodynamiki dla płynów rzeczywistych, a dynamikę mas dyskretnych równaniami jednowymiarowymi i również zidentyfikowano na podstawie wyników pomiarów $[9,10,12$ i 13]. Wymiana ciepła dla powietrza zawartego w pojedynczych zbiornikach kolejowych zidentyfikowana została przez autora $\mathrm{z}$ dużą dokładnością [11].

\section{Obliczenie hamowności i dynamiki pociągu}

Hamulec zespolony pociągu stanowi system, który dla celów modelowania można podzielić na układy:

- pneumatyczny

- mechanicznych przekładni hamulcowych

- par ciernych.

Układ mechaniczny i cierny domyka łańcuch obliczeń przebiegu procesu hamowania pociagu. Przedstawione modele tych elementów posiadają stopień szczegółowości wystarczający dla całopociaggowych analiz hamowania.

Wykorzystana metoda symulacyjna oparta jest na symulacji w funkcji czasu. W obliczeniach hamowności pociagu, w których przebieg zjawisk w układzie pneumatycznym jest uproszczony, można by stosować metodę całkowania równań ruchu po prędkości jazdy, co jest bardzo szybkim procesem obliczeniowym, jednak jej wadą jest brak możliwości obliczeń dynamiki pociągu.

Zaletą metody związania równań ruchu w funkcji czasu jest to, że pozwala na wyliczanie wprost wszelkich zmiennych dynamicznych: przyspieszeń, prędkości i drogi oraz umożliwia rozszerzenie analiz (nie dokonane w artykule) o dynamikę wzdłużną pociagu niesztywnego, pozwalającą na określenie nadwyżki dynamicznej sił zderznych lub pociągowych. Krok obliczeń symulacji układu pneumatycznego musi być przeważnie wielokrotnie mniejszy, niż wymaga tego obliczenie dynamiki wzdłużnej. Ten krótki krok czasowy powoduje, że także przy stosowaniu nie wyrafinowanych metod całkowania równań ruchu pociągu $\mathrm{w}$ funkcji czasu uzyska się dużą dokładność symulacji. Zastosowano więc prostą metodę linearyzacji odcinkowej przyspieszenia równań ruchu wagonów, a opóźnienie pociagu na początku n-tego kroku $\ddot{y}_{n}$ przyjęto jako uśrednione dla całego kroku obliczeń, uzyskując zależności typu otwartego (implicite):

$$
\begin{aligned}
& \dot{y}_{n+1}=\dot{y}_{n}+\ddot{y}_{n} \cdot d t \\
& y_{n+1}=y_{n}+\dot{y}_{n} \cdot d t+\frac{\ddot{y}_{n} \cdot d t^{2}}{2}
\end{aligned}
$$

Dla standardowych wagonów z jednym cylindrem hamulcowym na wagonie, wzór na uśrednione przyspieszenie pociagu przyjmie postać:

$$
\begin{array}{ll}
-y, \dot{y}, \ddot{y} & \begin{array}{l}
\text { przemieszczenie masy wa- } \\
\text { gonu i jego pochodne }
\end{array} \\
-\sum_{i} F_{\text {ham }, i} & \begin{array}{l}
\text { suma sił hamowania } \\
\text { wszystkich ,i” pojazdów } \\
\text { pociagu }
\end{array}
\end{array}
$$

gdzie:$$
\ddot{y}_{n}=\frac{\sum_{i} F_{\text {ham }, i}+\sum O p_{i}}{\sum_{i}\left(m_{\text {wag }, i} \cdot \rho_{i}\right)}
$$ 


$$
\begin{array}{cl}
-\sum_{i} O p_{i} & \begin{array}{l}
\text { suma oporów ruchu wszyst- } \\
\text { kich ,i” pojazdów pociagu }
\end{array} \\
-\sum_{i}\left(m_{w a g, i} \cdot \rho_{i}\right) \begin{array}{l}
\text { suma mas wszystkich ,„” } \\
\text { pojazdów pociagu wraz ze } \\
\text { współczynnikami } \rho \text { mas wi- } \\
\text { rujących. }
\end{array}
\end{array}
$$

Siła hamowania pojedynczego wagonu jest liczona na każdym kroku obliczeń z zależności:

$$
F_{\text {ham }, i}=\left(p_{c}-p_{s}\right) \cdot n \cdot j \cdot A t \cdot k_{h} \cdot \eta_{\mathrm{r}}
$$

gdzie:

$-A t$
$-F_{h a m, i}$
$-j$
$-k_{h}$
$-n$
$-p_{c}$
$-p_{s}$
$-\eta_{r}$

pole tłoka cylindra

siła hamowania przypadająca na jeden wagon

przełożenie układu dźwigniowe-

go

współczynnik tarcia elementu ciernego hamulca

liczba cylindrów hamulcowych przypadająca na jeden zestaw kołowy

chwilowe ciśnienie w cylindrze i-tego wagonu

ciśnienie na pokonanie oporu sprężyny w cylindrze

sprawność układu dźwigniowego.

Współczynnik tarcia elementów ciernych hamulca przyjęto $\mathrm{w}$ postaci zależności liniowej od prędkości jazdy i nacisku na element cierny:

$$
k_{h}=k_{1}+k_{2} \cdot v+k_{3} \cdot N
$$

gdzie:

$k_{1} \div k_{3}-$ współczynniki liczbowe

$v$ - prędkość jazdy $[\mathrm{m} / \mathrm{s}]$

$N$ - nacisk na element cierny [N].

Zamodelowany współczynnik tarcia dla hamulca klockowego jest zgrubnym przybliżeniem, natomiast dla hamulca tarczowego odzwierciedla $\mathrm{z}$ większą dokładnością rzeczywistość.

Suma oporów ruchu pociagu dana jest sumarycznym wzorem

$\sum_{i} O p_{i}=\left(w s p o p 1+w \operatorname{spop} 2 \cdot v+w \operatorname{spop} 3 \cdot v^{2}\right) \cdot \sum_{i} m_{w a g, i}$

gdzie:

- wspop współczynniki oporów.

Obliczenie sił występujących w urządzeniach pociągowo-zderznych, przy pominięciu odkształceń tych urządzeń w modelu (nazywanym pociagiem sztywnym), a co za tym idzie bez nadwyżek dynamicznych występujących przy nabieganiu na siebie wagonów, dane jest zależnością rekurencyjną:

$$
\begin{aligned}
F_{m w}, i & =F_{m w, i-1}+F_{\text {ham }, i}-\ddot{y} \cdot m_{\text {wag }, i} \quad \begin{array}{l}
\mathrm{i}=1, \\
\text { ilość wago- } \\
\text { nów }
\end{array}
\end{aligned}
$$

gdzie:

- $\mathrm{F}_{\mathrm{mw}, \mathrm{i}}, \quad$ siła $\mathrm{w}$ urządzeniach międzywagonowych po i-tym wagonie.

Określenie sił w pociągu sztywnym jest pewnym uproszczeniem rzeczywistości, ale pozwala na uogólniony wpływ nierówności sił hamowania wagonów w pociagu niezależnie od charakterystyki urządzeń pociagowo-zderznych.

Zarówno metoda modelowania układu pneumatycznego hamulca jak i metoda określania hamowności pociagu zostały wykorzystane $\mathrm{w}$ autorskim programie symulacyjnym (nie publikowanym), który posłużył do przeprowadzenia analiz symulacyjnych zaprezentowanych w punkcie 4.

Dynamikę wzdłużną pociąu $\mathrm{z}$ podatnymi urządzeniami międzywagonowymi analizowaną metodą symulacyjną szczegółowo rozpatrzono przez autora $\mathrm{w}$ [5].

\section{Wpływ budowy pneumatycznego hamulca na skuteczność jego dzialania}

umatyczne układy hamulcowe pojazdów szynowych są ciaggle udoskonalane. Istnieją lub wraz z rozwojem techniki pojawiają się nowe problemy dotyczące działania i konstrukcji pneumatycznego układu hamulcowego, które wymagają rozwiązań. Część z nich nosi jednak znamiona uniwersalności.

Ogólnie radykalne polepszenie skuteczności hamulca kolejowego można by osiagnąć stosując dużo szerzej w hamulcu kolejowym sygnał elektryczny. Prędkość rozchodzenia impulsu elektrycznego wzdłuż pociagu jest wielokrotnie większa, niż impulsu pneumatycznego i nie thumiona, co pozwoliłoby wyrównać siły hamowania wszystkich wagonów i umożliwiło zmniejszyć czasy wzrostu siły hamowania. W dobie dynamicznego rozwoju elektrotechniki i elektroniki stosuje się elementy sterowania elektrycznego. Przykładem są np. częściowo elektroniczne zawory maszynisty i rozrządcze, elektroniczne urządzenia przeciwpoślizgowe, hamulce szynowe. Jednakże w sytuacjach awaryjnych ruchu kolejowego, zwłaszcza w ruchu towarowym, i różnych ekstremalnych warunkach klimatycznych musi być osiagnięta pewność hamowania, co zapewnia hamulec pneumatyczny. W grę wchodzą również względy ekonomiczne.

patrując parametry przewodu głównego, zagadnienie rozważano przyjmując realistycznie parametry pneumatycznego układu hamulca oraz w zakresie dopuszczalnym przepisami kolejowymi. Omówiono przykładowe analizy wpływu głównych parametrów układu przewodu głównego. W obliczaniu hamowności pociągu przyjęto stały współczynnik tarcia 
par ciernych i pominięto opory ruchu, by nie zniekształcać dokładności wpływu układu hamulcowego na hamowność pociagu. Przyjęto średnią wartość współczynnika tarcia i przełożenie układu dźwigniowego tak, że dla pojedynczego wagonu procent ciężaru hamującego wagonu pełnego przy hamowaniu $\mathrm{z}$ $100 \mathrm{~km} / \mathrm{h}$ osiaga wartość $98 \%$.

Prezentowanymi wynikami symulacji są w większości przypadków: prędkość fali hamowania, czas napełnienia cylindra ostatniego wagonu (do $95 \%$ ciśnienia maksymalnego), droga hamowania pociagu oraz maksymalne siły wzdłużne dla modelu pociąu sztywnego. Dla wybranych wariantów zaprezentowano na wykresach w funkcji czasu przebiegi ciśnień w
PG, w cylindrach hamulcowych pierwszego i co 10tego wagonu oraz sił wzdłużnych dla sprzęów międzywagonowych po pierwszym i co piatym wagonie. Dla pociagu krótszego zastosowano gęstszy podział.

Wartości sił wzdłużnych w pociągu z rzeczywistymi podatnymi sprzęgami są znacznie większe, niż dla modelu pociagu sztywnego, co wykazano np. w [4 i 5].

\subsection{Zbiorcze zestawienie wyników symulacji}

W tabeli 1 zamieszczono syntetyczne wyniki wszystkich omówionych procesów, a wyniki symulacji wybranych wariantów zaprezentowano przy ich omawianiu, w postaci analogicznej do rys. 1a.

Zbiorcze zestawienie skuteczności hamowania rozpatrywanych wariantów

Tabela 1

\begin{tabular}{|c|c|c|c|c|c|c|c|}
\hline L.p.. & $\begin{array}{l}\text { hamo- } \\
\text { wanie }\end{array}$ & $\begin{array}{c}\text { nastawie- } \\
\text { nie ha- } \\
\text { mulca }\end{array}$ & stan wagonów i aparatury hamulcowej & $\begin{array}{c}\text { pręd- } \\
\text { kość fali } \\
\text { hamo- } \\
\text { wania } \\
{[\mathrm{m} / \mathrm{s}]}\end{array}$ & $\begin{array}{l}\text { czas napeł- } \\
\text { niania cy- } \\
\text { lindra } \\
\text { ostatniego } \\
\text { wagonu [s] }\end{array}$ & $\begin{array}{l}\text { droga ha- } \\
\text { mowania } \\
{[\mathrm{m}]}\end{array}$ & $\begin{array}{c}\text { maks. siła } \\
\text { wzdłużna } \\
{[\mathrm{kN}]}\end{array}$ \\
\hline 1 & nagłe & osobowy & pojedynczy wagon & & 4,49 & 487,9 & - \\
\hline 2 & nagłe & towarowy & pojedynczy wagon & & 18,0 & 651,9 & - \\
\hline 3 & nagłe & osobowy & $\begin{array}{l}\text { PG nominalny (nierówności PG } \mathrm{k}=0,16 \\
\mathrm{~mm} \text { ) }\end{array}$ & 285,7 & 17,45 & 609,9 & 502,3 \\
\hline 4 & nagłe & towarowy & PG nominalny $(\mathrm{k}=0,16$, zaskok 0,35 bar) & 285,7 & 20,30 & 688,7 & 91,8 \\
\hline 5 & nagłe & osobowy & duża przewodność cieplna PG $(\mathrm{k}=0,16)$ & 285,0 & 17,76 & 617,0 & 510,7 \\
\hline 6 & nagłe & osobowy & mała przewodność cieplna PG $(\mathrm{k}=0,16)$ & 288,7 & 15,83 & 589,7 & 485,1 \\
\hline 7 & nagłe & osobowy & PG bardziej gładki $(\mathrm{k}=0.05 \mathrm{~mm})$ & 291,6 & 16,12 & 597,8 & 490,0 \\
\hline 8 & nagłe & osobowy & PG bardziej chropowaty $(\mathrm{k}=0,4 \mathrm{~mm})$ & 268,9 & 20,52 & 637,3 & 521,6 \\
\hline 9 & nagłe & osobowy & PG krótki ( 400 m, k=0,16) & 287,1 & 7,15 & 515,1 & 144,1 \\
\hline 10 & nagłe & osobowy & PG z dużymi odgałęzieniami po $4,2 \mathrm{~m}$ & 219,8 & 26,67 & 690,4 & 503,6 \\
\hline 11 & nagłe & osobowy & PG z niewielkimi odgałęzieniami $0,98 \mathrm{~m}$ & 264,1 & 19,98 & 634,8 & 512,6 \\
\hline 12 & nagłe & osobowy & PG o średnicy $1 "$ & 289,2 & 16,16 & 587,7 & 489,6 \\
\hline 13 & nagłe & osobowy & $\begin{array}{l}\text { większy przelot zaworu maszynisty } \\
(\Phi=22,6 \mathrm{~mm})\end{array}$ & 288,2 & 16,05 & 593,3 & 533,6 \\
\hline 14 & nagłe & osobowy & kurki końcowe 1" & 281,1 & 18,60 & 620,5 & 510,8 \\
\hline 15 & nagłe & osobowy & $\begin{array}{l}\text { nominalny, zawory rozrządcze bez przy- } \\
\text { spieszaczy }\end{array}$ & 127,4 & 19,41 & $650,3 *$ & $599,8 *$ \\
\hline 16 & nagłe & osobowy & $\begin{array}{l}\text { hipotetyczny prosty pneumatyczny } \\
\text { sprzęg międzywagonowy }\end{array}$ & 298,5 & 15,00 & 587,9 & 478,0 \\
\hline 17 & nagłe & towarowy & większe ciśnienie zaskoku ( 0,7 bar) & 285,7 & 20,31 & 671,5 & 137,6 \\
\hline 18 & nagłe & towarowy & $\begin{array}{l}\text { nominalny, zawory rozrządcze bez przy- } \\
\text { spieszaczy }\end{array}$ & 127,1 & 25,88 & $811,9 *$ & $252,5 *$ \\
\hline 19 & służbowe & osobowy & nominalny & 275,2 & 42,93 & $942,9,6$ & 99,6 \\
\hline 20 & służbowe & osobowy & $\begin{array}{l}\text { nominalny, zawory rozrządcze bez przy- } \\
\text { spieszaczy }\end{array}$ & 56,1 & 52,58 & $1153,4 *$ & $150,5 *$ \\
\hline 21 & służbowe & towarowy & nominalny & 275,2 & 42,93 & 960,7 & 126,6 \\
\hline 22 & służbowe & towarowy & $\begin{array}{l}\text { nominalny, zawory rozrządcze bez przy- } \\
\text { spieszaczy }\end{array}$ & 56,1 & 52,58 & $1168,3 *$ & $217,9 *$ \\
\hline
\end{tabular}

* wartość zależna znacznie od parametrów zaworu rozrzqdczego 


\subsection{Układ odniesienia dla porównań układów hamulcowych}

Jako przebieg odniesienia wybrano hamowanie nagłe pociągu złożonego z 50 wagonów towarowych o długości PG po $14 \mathrm{~m}$, plus lokomotywa; PG posiada średnice 11/4" i kurki końcowe 1/1/4". Przewód główny jest prosty i bez rozgałęzień. Założono PG eksploatowany przez pewien czas; dla rury walcowanej lekko zanieczyszczonej przyjęto chropowatość ścianek 0,16 $\mathrm{mm}$. Wartość łącznego współczynnika przenikania ciepła na jednostkę długości rury założono 2,41 $[\mathrm{W} /(\mathrm{m} \cdot \mathrm{K})]$. Przyjęto zawory rozrządcze ESt3f dla nastawienia „osobowy” bez zaskoku, a w nastawieniu

a)
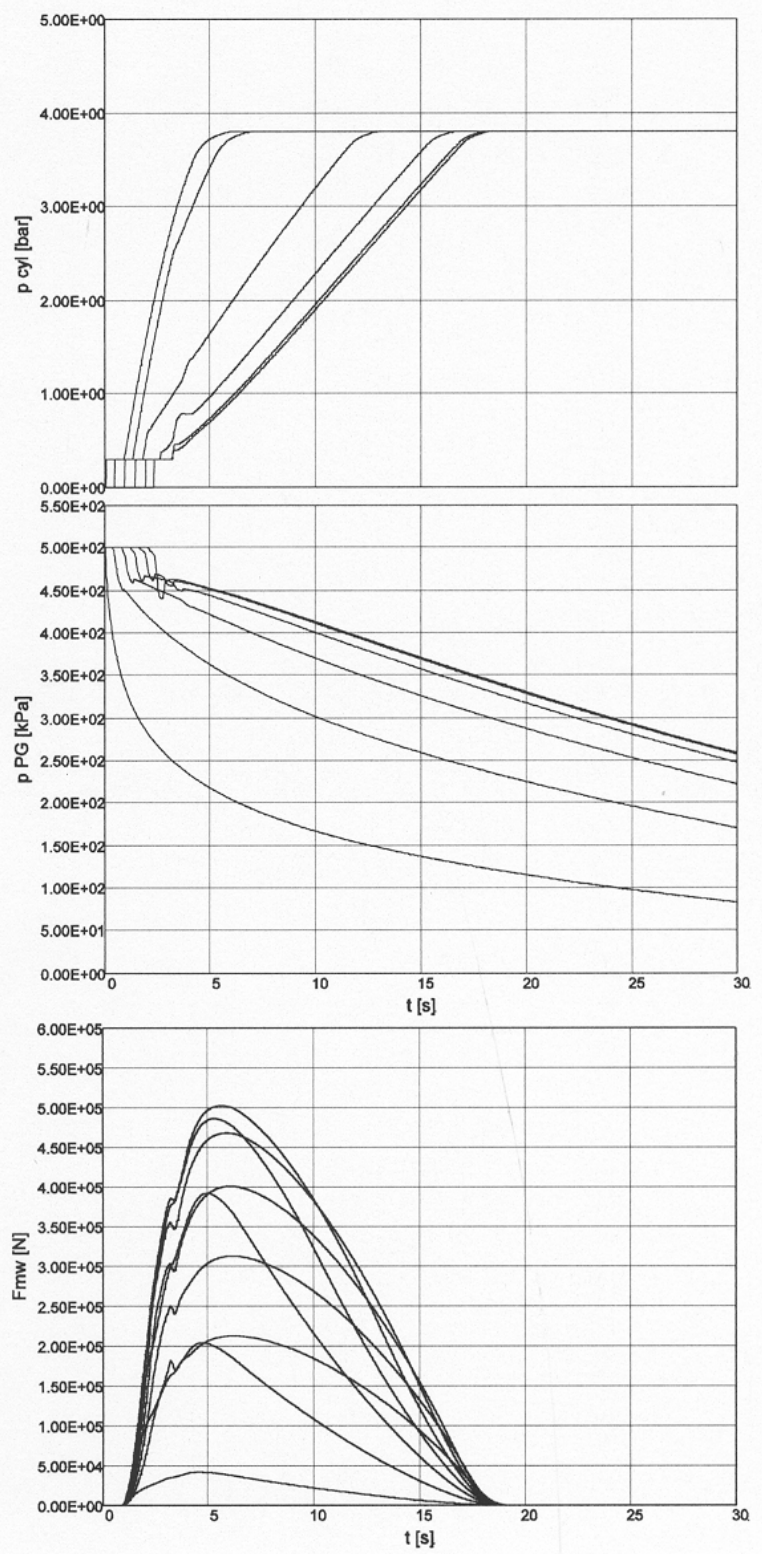

„towarowy” z zaskokiem 0,35 bar; cylindry hamulcowe posiadają średnicę 16", a zbiorniki pomocnicze posiadają pojemność 751 . Konstrukcję innych wariantów określa się względem tego wariantu odniesienia. Analizowano głównie hamowanie nagłe z nastawieniem zaworów rozrządczych „osobowy” (bo w tym nastawieniu wyniki pozwalają na bardziej przejrzyste uogólnienia), ale normalnie pociagi o długości powyżej $400 \mathrm{~m}$ posiadają w rzeczywistości nastawienie „towarowy”. Wyniki symulacji hamowania nagłego przedstawiono na rys. 1a, a na rys. 2 dodatkowo zamieszczono wyniki przebiegu sił wzdłużnych w funkcji położenia sprzęgu w pociagu co jedną sekundę w przedziale czasu występowania największych sił. b)
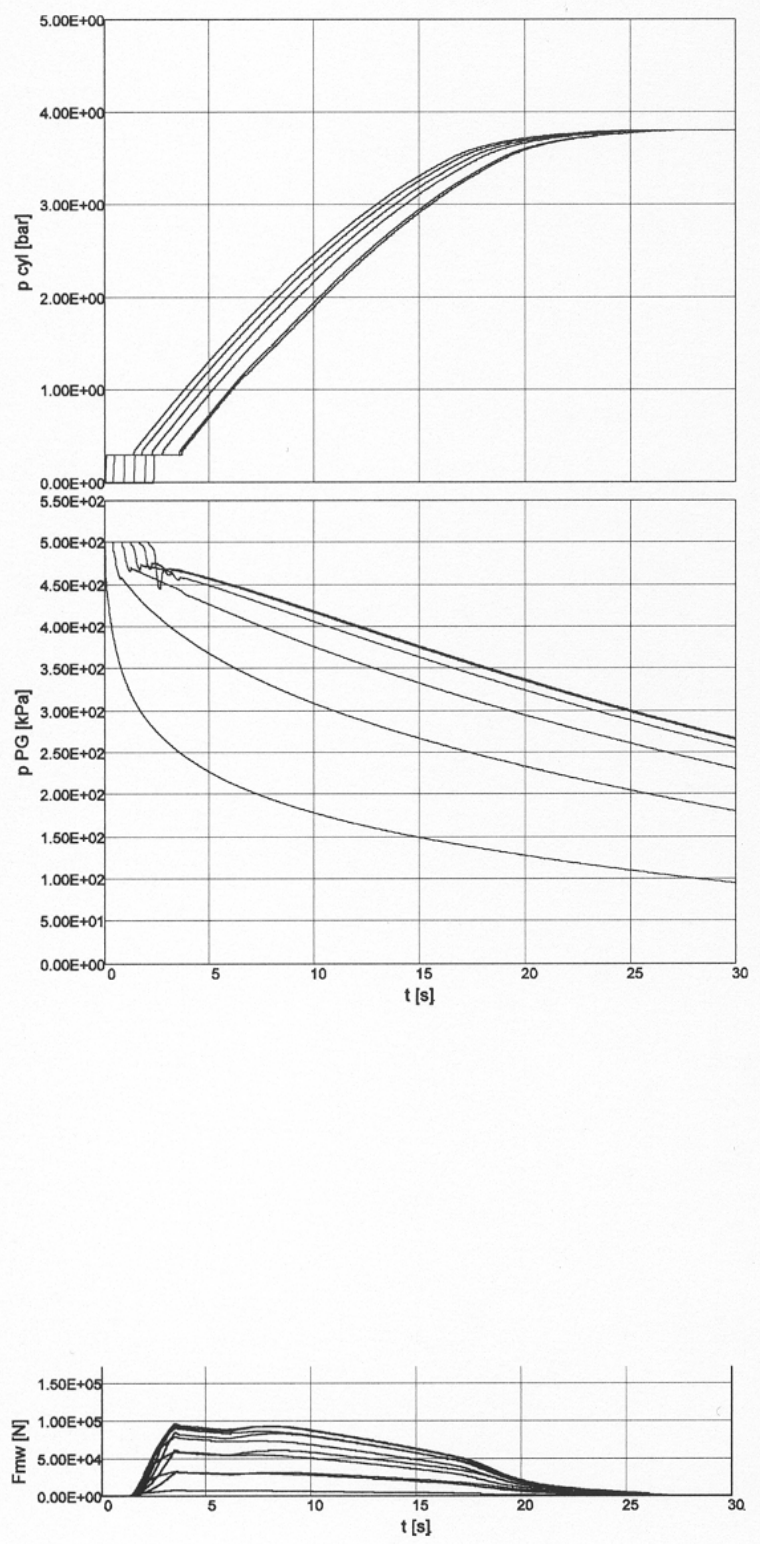

Rys 1 . Przebieg symulacyjny hamowania pociagu nominalnego 50 wagonowego: ciśnienia w PG i cylindrach hamulcowych oraz siły wzdłużne w funkcji czasu: a) nastawienie „osobowy”, b) nastawienie „towarowy” (objaśnienia w tekście) 


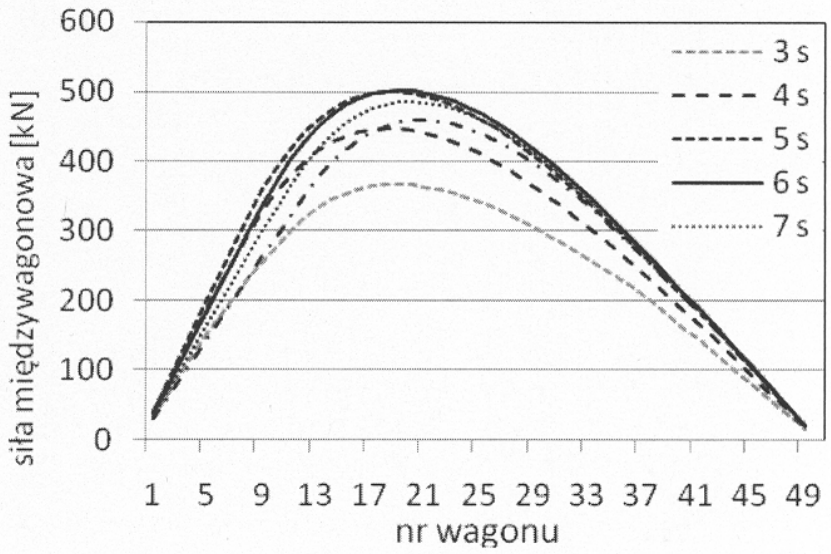

Rys. 2. Przebieg sił międzywagonowych w czasie hamowania wg rys. 1a w funkcji położenia sprzęgu międzywagonowego w pociagu dla wybranych chwil czasowych

\subsection{Omówienie porównania wariantów}

\subsubsection{Dlugość przewodu głównego}

Im większa jest długość PG, tym pogarszają się warunki sterowania układem hamulcowym. Dla krótkich składów znika wiele problemów hamowania pociagu. Przewód główny musi obejmować cały skład pociagu, więc konstruktor ma niewielki wpływ na jego długość. Jednakże ważne jest, by przewód nie posiadał nadmiernej długości na wagonie i był w miarę

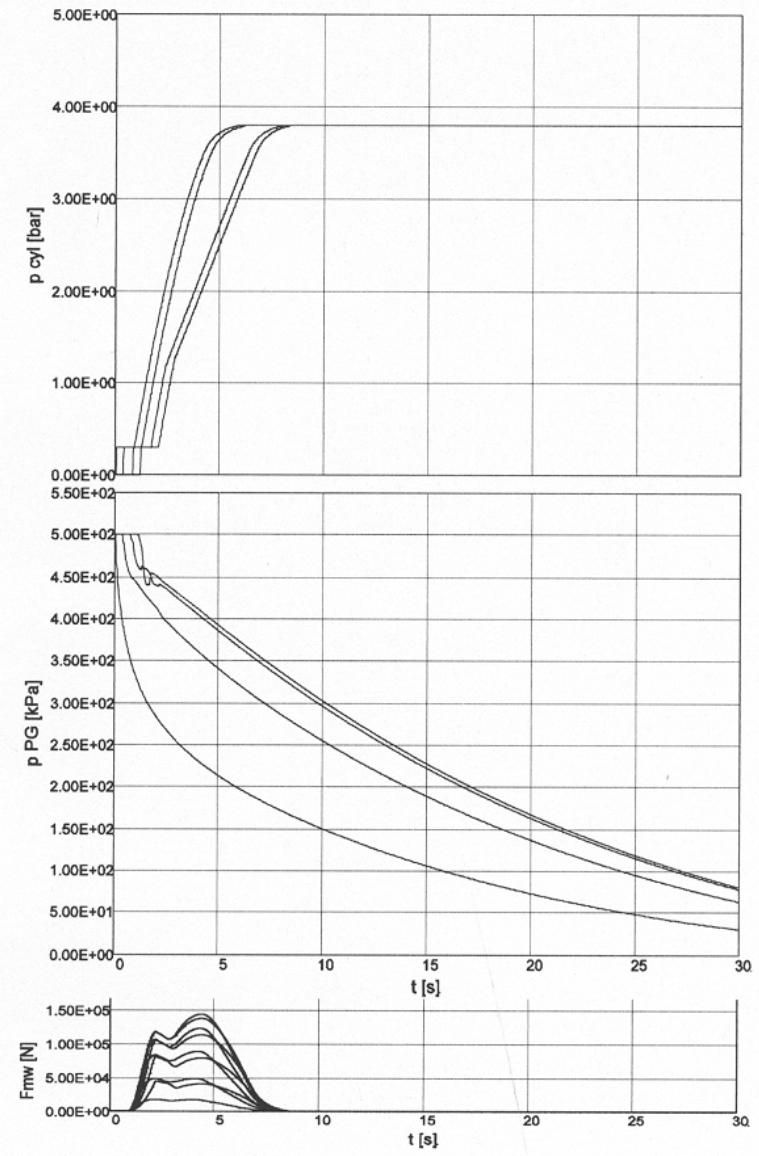

Rys 3. Hamowanie nagłe pociagu 392 m (27 wag.); wyniki dla pierwszego i co 9 wagonu prosty. Dla dłuższych, niż składane w Europie, pociągów należałoby zmienić ustawienia całego układu. Na rys. 3 przedstawiono wynik hamowania nagłego pociągu krótszego niż nominalny, złożonego z 27 wagonów + lokomotywa (długość $392 \mathrm{~m}$ ). Widoczne jest radykalne polepszenie napełniania cylindrów dla pociągu krótszego. Jak widać na rys. 3 z przebiegu ciśnienia $\mathrm{w}$ cylindrach, nieco krótszy pociąg niż 27 wagonów jest granicznym składem, przy którym dla nastawienia „osobowy” nie byłoby opóźnienia napełniania ostatnich wagonów pociągu.

\subsubsection{Czas napelniania cylindra}

Zasadniczą metodą zmniejszenia sił wzdłużnych, niezbędną dla długich pociągów towarowych, jest wydłużenie nominalnego czasu napełniania cylindra (w symulacjach z 4,5 s do 18,0 s) dla nastawienia „towarowy”. Nastawienie hamulców na „towarowy” powoduje wydłużenie drogi hamowania dla pojedynczego wagonu z 487,9 do 651,9 m (o 34\%), nominalnego pociagu o długości $700 \mathrm{~m} \mathrm{z} 609,9$ do $688,7 \mathrm{~m}$ (o 13\%); jednak maksymalne wartości sił wzdłużnych spadły ponad pięciokrotnie z 502,3 do $91,8 \mathrm{kN}$. Wykresy dla pociagu $700 \mathrm{~m} \mathrm{z}$ nastawieniem ,towarowy” przedstawiono na rys. $1 \mathrm{~b}$.

\subsubsection{Przekrój przewodu głównego}

Przewód główny przed kilkudziesięciu laty posiadał średnicę 1". Aby polepszyć jego działanie dla napełniania układu hamulca, średnicę zwiększono do $11 / 4$ ", a w obecnym czasie zwiększa się również przelot kurków końcowych do średnicy 11/4". Dla hamowania nagłego wprowadzenie przewodu 11/4" spowodowało (wg symulacji) niewielkie niekorzystne wydłużenie czasu napełniania ostatniego cylindra o 2,4 s, a wprowadzenie zaworów końcowych o większym przelocie pozwoliło zmniejszyć wydłużenie czasu napełniania ostatniego cylindra do 1,3 s. Zastosowanie wcześniej PG o średnicy 1" powodowało skrócenie drogi hamowania o 3,6 \% i zmniejszenie sił wzdłużnych o $2,5 \%$.

Duży zysk uzyskano natomiast dla napełniania układu (dla zaworu maszynisty FV4a i stałego ciśnienia $\mathrm{w}$ zbiorniku głównym równego 9,5 bar); przewód 11/4" daje krótsze (z 240 do $164 \mathrm{~s}$ ) o ok. $76 \mathrm{~s}$ odhamowanie $\mathrm{z}$ pozycji hamowania nagłego, co przedstawiono na rys. 4.

Należy jednak zaznaczyć, że zbyt mała wydajność sprężarki i pojemność zbiornika głównego mogą znacznie wydłużyć odhamowanie.

W nowych konstrukcjach wprowadza się kurki końcowe $11 / 4$ ". Są one korzystniejsze, niż kurki 1", zmniejszenie drogi hamowania nie przekracza jednak $2 \%$. 
a)

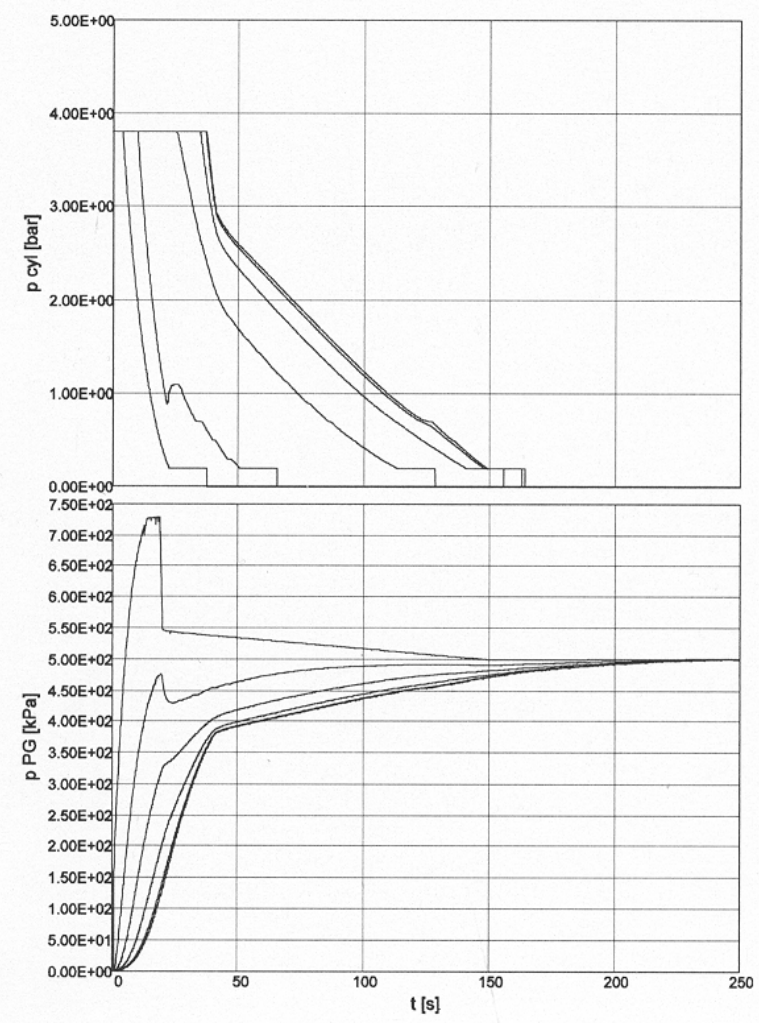

b)

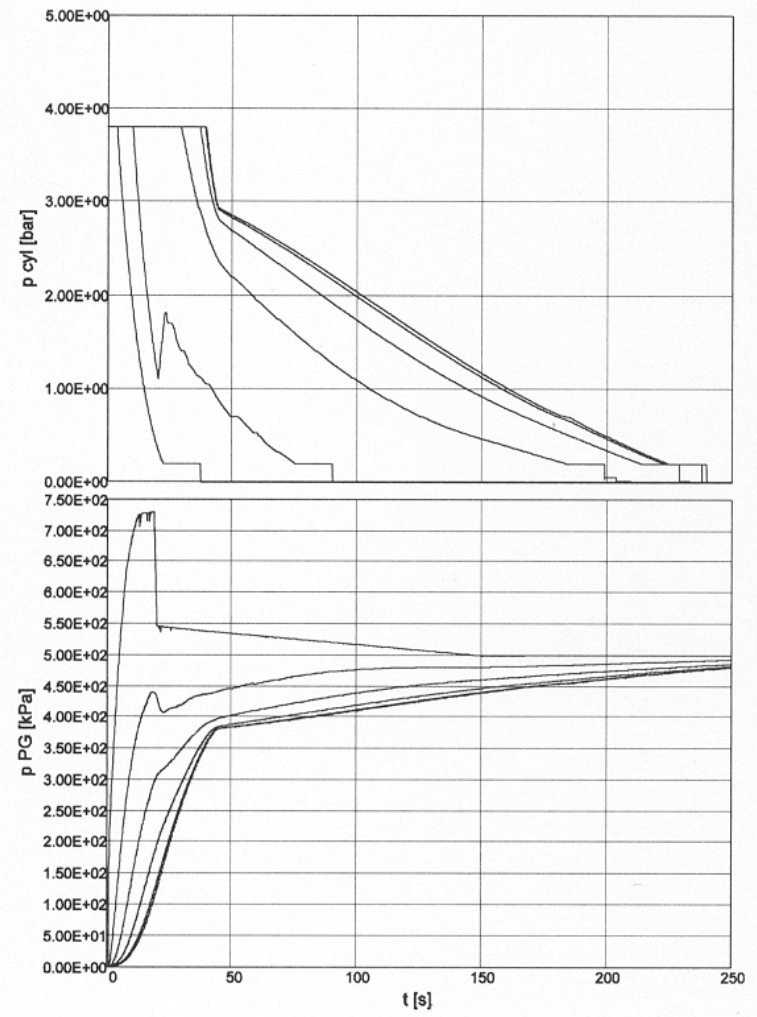

Rys 4. Porównanie przebiegu odhamowania po hamowaniu nagłym: a) dla PG 1 1⁄a", b) dla PG 1"

\subsubsection{Opór przewodu głównego}

Wszelkie zmniejszenie oporu przepływu ma korzystny wpływ na pracę układu hamulcowego; można to zrealizować na dwa sposoby przedstawione poniżej:

- Zmniejszyć opór tarcia przez zwiększenie gładkości ścianek. Na PG wykorzystuje się rury stalowe walcowane surowe, które po dłuższym czasie pracy mogą skorodować. Porównanie wyników symulacji hamowania nagłego dla przyjętych trzech chropowatości przewodu przedstawia tabela 1 . Dla nowego przewodu o dużej stosunkowo gładkości przyjęto bezwzględną wysokość nierówności $0,05 \mathrm{~mm}$, dla normalnie eksploatowanego przewodu nieco zanieczyszczonego przyjęto nierówności $0,16 \mathrm{~mm}$, a nieco skorodowanego przewodu $0,4 \mathrm{~mm}$. Jak wynika $\mathrm{z}$ tabeli 1 (L.p. 3, 7 i 8) utrzymywanie PG nieskorodowanego jest wystarczające dla niepogarszania efektywności hamowania; dodatkowe przedsięwzięcia dla zapewnienia gładkości przewodu nie sa opłacalne, gdyż niewielki, nieznaczący zysk efektywności można osiaggnąć taniej innymi przedsięwzięciami.

- Zmniejszyć opory lokalne przez zredukowanie zmian przekrojów oraz ukształtowanie możliwie prostego PG. Przewód główny z natury rzeczy składa się z bardzo wielu elementów składowych i po- szczególne elementy złączne powtarzane wielokrotnie mogą znacznie zmienić łączne opory. Również w Polsce w nowych konstrukcjach taboru wykorzystuje się połączenie kolejnych rur PG złączami zaciskowymi zewnętrznymi bez zmiany przekroju przelotu (takie też przyjęto dla wariantu odniesienia). Ważne jest jednak, by kolejne odcinki rury stykały się z sobą, gdyż rozsunięcie styku powoduje chwilowy skok przekroju i dodatkowe opory. Należy unikać uszczelnień czołowych, które mogą wywołać zakłócenia przepływu (np. uszczelka czołowa może się zdeformować i zwęzić przekrój PG). Nowoczesne trójniki kolejowe do odgałęzienia PG przy czołownicy są już zoptymalizowane. Posiadają niewielki kąt rozgałęzienia, łączone z rurami PG przez zacisk i dobrze zmontowane nie powoduja zmiany przekroju. Odgałęzienia do zaworów rozrządczych w standardowym układzie hamulcowym są zblokowane ze wspornikami zaworów mocowanymi bezpośrednio na PG i powodują niewielki opór przepływu. Jeżeli zawór rozrządczy mocowany jest na dłuższym odgałęzieniu, to winno ono posiadać mniejszy niż PG przekrój, co powoduje zmniejszenie objętości odgałęzienia. 


\subsubsection{Zlącze międzywagonowe}

Odrębnym zagadnieniem jest zespół sprzęgu międzywagonowego. Sam sprzęg jest zespołem znormalizowanym dla wszystkich normalnych wagonów. Posiada prześwit nominalny 1 " i stosunkowo duże opory.

Do zespołu międzywagonowego należą również kurki końcowe. Wpływ ich rozmiaru przedstawiono przy analizie przekroju przewodu.

Możliwością radykalnego zmniejszenia oporów byłoby zastosowanie automatycznego sprzęgu pneumatycznego $\mathrm{z}$ dobrze ukształtowanymi kanałami. Przeprowadzono symulację $\mathrm{z}$ takim hipotetycznym (oszacowanym) sprzęgiem międzywagonowym. Droga hamowania zmniejszyła się o 3,6 \%, a siły wzdłużne o $4,8 \%$.

\subsubsection{Odgałęzienia przewodu głównego}

Odgałęzienia przewodu są koniecznym elementem PG, ale szkodliwym, jeżeli chodzi o jego działanie. Jest to niekiedy duży problem konstrukcji PG.

a)
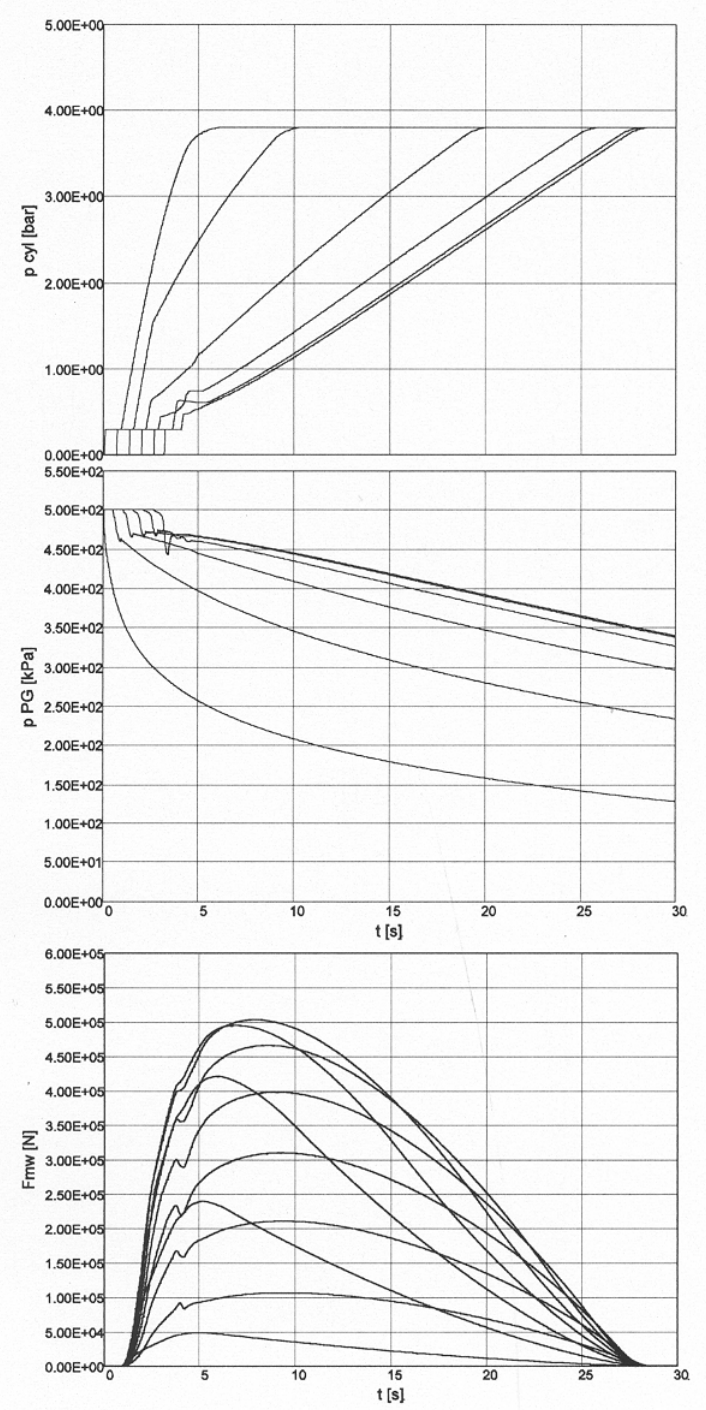

Konieczne odgałęzienia do dwóch sprzęgów hamulcowych na czołownicy w zależności od ich przebiegu moga powodować znaczne zmniejszenie efektywnej prędkości fali hamowania. W tab. 1, poz. 11 przedstawiono wyniki hamowania dla PG z możliwie małymi odgałęzieniami - dwa odgałęzienia po $0,98 \mathrm{~m}$ na wagon (minimalna długość zadana wymaganiami konstrukcyjnymi). W tab.1, poz. 10 i na rys. 5a przedstawiono wyniki dla wagonu $\mathrm{z}$ dużymi odgałęzieniami PG, jakie występują w wagonach towarowych, w których rozwidlenie PG mija kieszeń do zabudowy amortyzatora sprzęgu samoczynnego (dwa odgałęzienia po ok. 4,2 $\mathrm{m}$ na wagon). Dla niewielkich rozgałęzień pogorszenie parametrów układu hamulcowego jest niewielkie. Natomiast dla dużych odgałęzień prędkość fali hamowania została zmniejszona o $66 \mathrm{~m} / \mathrm{s}$, a czas napełniania ostatniego cylindra wydłużył się z 17,5 s do 26,7 s. Spowodowało to wydłużenie drogi hamowania o $13 \%$ przy praktycznie nie zmienionych maksymalnych siłach wzdłużnych. W nowoczesnym taborze zaleca się unikanie dużych odgałęzień dających tak zły przebieg hamowania.

b)
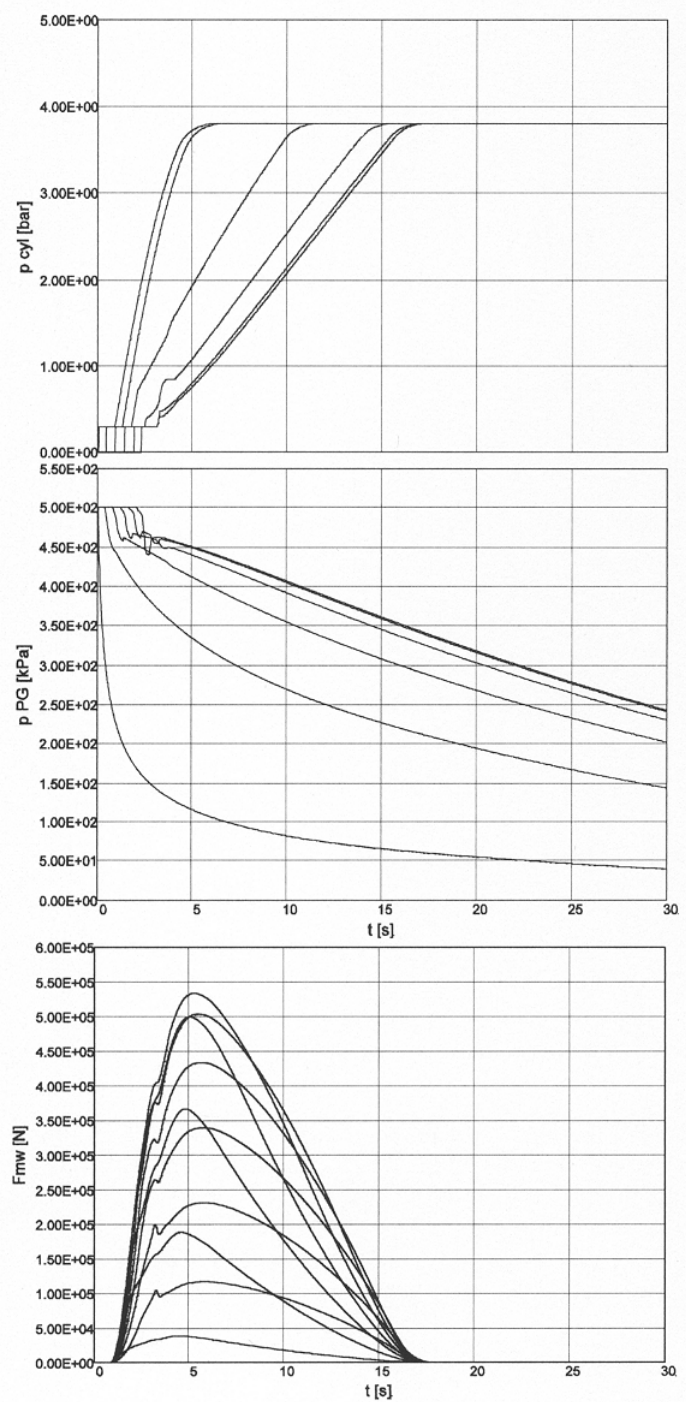

Rys 5. Hamowanie nagłe poc. $700 \mathrm{~m}$ : a) wagony z dużymi odgałęzieniami, b) wylot zaworu maszynisty o średnicy $22,6 \mathrm{~mm}$ 


\subsubsection{Wymiana ciepła}

Elementy układu hamulcowego nie posiadają izolacji termicznej od otoczenia i jest to zbędne. Ograniczone przenikanie ciepła przez ścianki PG byłoby pomocne $\mathrm{w}$ uzyskaniu przemiany adiabatycznej $\mathrm{w}$ trakcie rozchodzenia się fali zaburzenia, ale w dalszych fazach procesu hamowania mogłoby wywoływać niekorzystne zjawiska, np. zmiany siły hamowania $z$ powodu zmiany temperatury powietrza $\mathrm{w} P \mathrm{PG} i$ aparatach. Czterokrotne zmniejszenie współczynnika przewodzenia ciepła w symulacji od nominalnego (do wartości $0,64 \mathrm{~W} /(\mathrm{m} \cdot \mathrm{K}))$ spowodowało wzrost prędkości fali hamowania o 3,0 m/s i zmniejszenie czasu napełniania ostatniego cylindra o 1,6 s. Podwójne zwiększenie przewodzenia ciepła $\mathrm{w}$ symulacji (do $4,82 \mathrm{~W} /(\mathrm{m} \cdot \mathrm{K}))$ praktycznie nie zmieniło działania układu. Układ rur nieizolowanych jest rozwiązaniem korzystnym, a niewielkie zmiany przyjętej przewodności bardzo nieznacznie zmieniają wyniki symulacji.

\subsubsection{Przepustowość zaworu maszynisty}

Jej dobór jest przykładem wielokryterialności działania układu pneumatycznego hamulca kolejowego. W nastawieniu jazda przepustowość nie może być zbyt duża, gdyż maszynista nie miałby informacji o szczelności układu hamulcowego. W nastawieniach hamowanie i odhamowanie zbyt mała przepustowość byłaby powodem powolnych zmian ciśnienia w PG, a więc również zmian ciśnienia $\mathrm{w}$ cylindrze, a nadmierna przepustowość powodowałaby nierówność sił hamujących wzdłuż składu pociągu i jego szarpnięcia. Dla napełniania lub odhamowania uderzeniowego można dokonać pewnego polepszenia pracy układu: duża wydajność zaworu maszynisty jest bardzo pożądana, ale musi być ograniczona czasowo, by nie przepełnić zbiorników sterujących [6]. Również dla hamowania nagłego przepustowość nie jest limitowana. Wyniki analiz zwiększenia przelotu w PG przedstawiono $\mathrm{w}$ tabeli 2 . Wynika $\mathrm{z}$ nich, że znaczne zwiększanie przelotu nie jest jednak efektywne. Wartości średnicy przelotu rzędu 12 do $15 \mathrm{~mm}$ wydają się rozsądne (w FV4a wartość ta wg identyfikacji wynosi ok. $12,4)$.
Brak zwiększenia efektywności dla dużych przelotów związany jest z wpływem rozciągłego po długości PG oporu przepływu. W PG pierwszego wagonu spadek ciśnienia jest gwałtowny, ale dla końca pociagu jest bardzo zbliżony do wyników pociagu nominalnego, co uwidoczniono na rys. 5b. Zastosowanie dużego wylotu spowodowało niewielkie zmniejszenie drogi hamowania, ale również niewielkie zwiększenie maksymalnych sił wzdłużnych (tabela 1, 1.p. 13).

\subsubsection{Hamowanie slużbowe}

Uprzednio analizowano hamowanie nagłe stosowane w sytuacjach ekstremalnych. W trakcie normalnych hamowań pociagu stosowane jest natomiast hamowanie służbowe. Charakteryzuje się dużo mniejszym przelotem zaworu maszynisty i opróżnianiem przewodu do ciśnienia niewiele mniejszego niż 0,35 $\mathrm{MPa}$.

Wyniki zawarte w tabeli 1 (1.p. 19 i 21 ) i na rys. 6 wskazują, że prędkość fali hamowania w porównaniu $\mathrm{z}$ hamowaniem nagłym przy poprawnie działających wszystkich przyspieszaczach zmniejsza się niewiele ( o ok. $10 \mathrm{~m} / \mathrm{s}$ ), ale czas napełniania ostatniego cylindra wzrasta ponad dwukrotnie. Opóźnienie napełniania cylindrów powoduje wydłużanie drogi hamowania pociagu o $40 \div 50 \%$. Jednocześnie jednak dla nastawienia „osobowy” pozwala na nawet pięciokrotne zmniejszenie sił wzdłużnych. Dla nastawienia „towarowy" sytuacja jest dużo korzystniejsza, bo siły wzdłużne są kilkakrotnie mniejsze, wpływ jest niejednoznaczny i silnie zależny od wartości zaskoku.

\subsubsection{Czułość-nieczułość zaworów rozrządczych}

Wiąże się ona z przepustowością dysz napełniania zbiornika sterującego w zaworze rozrządczym i rzutuje na odporność na przepełnienie tego zbiornika. Bez uwzględnienia doświadczeń z praktyki kolejowej nie sposób podać optymalnej przepustowości. Przez rozbudowanie zaworu rozrządczego można osiagnąć złożone napełnianie zbiornika sterującego i uzyskać większą odporność na przepełnienie, a również korzystną nieczułość w pozycji ,jazda". Przykładami są „pamięć” w zaworze ESt3 lub blokada połączenia ze zbiornikiem sterującym aż do końca napełnienia zbiornika pomocniczego w zaworze SW4-C.

Dla normalnych hamulców (z przyspieszaczami) zmiana czułość-nieczułość nie ma dużego wpływu na drogę hamowania i dlatego wykresów nie zamieszczono.

\begin{tabular}{|c|c|c|c|}
\hline $\begin{array}{c}\text { średnica efek- } \\
\text { tywna dyszy ha- } \\
\text { mowania nagłego } \\
{[\mathrm{mm}]}\end{array}$ & $\begin{array}{c}\text { prędkość fali ha- } \\
\text { mowania [m/s] }\end{array}$ & $\begin{array}{c}\text { Tabela 2 } \\
\text { czas spadku ciśnienia } \\
\text { w PG ostatniego wa- } \\
\text { gonu [s] o 1,5 bar }\end{array}$ & $\begin{array}{c}\text { czas napełniania } \\
\text { ostatniego cylin- } \\
\text { dra [s] }\end{array}$ \\
\hline 8,8 & 283,6 & 21,82 & 20,80 \\
\hline 10,6 & 285,0 & 19,44 & 18,55 \\
\hline 12,40 & 285,7 & 18,28 & 17,45 \\
\hline 17,50 & 286,3 & 17,11 & 16,35 \\
\hline 22,6 & 288,2 & 16,81 & 16,05 \\
\hline
\end{tabular}


a)

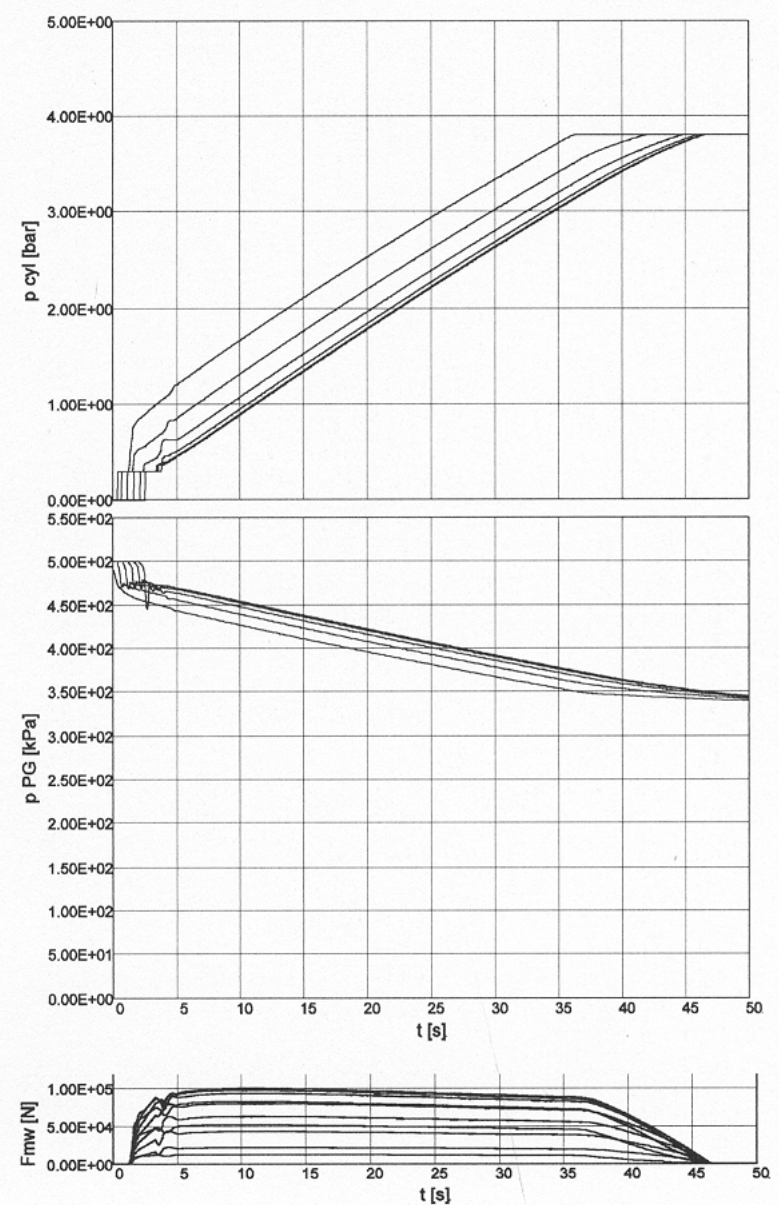

b)

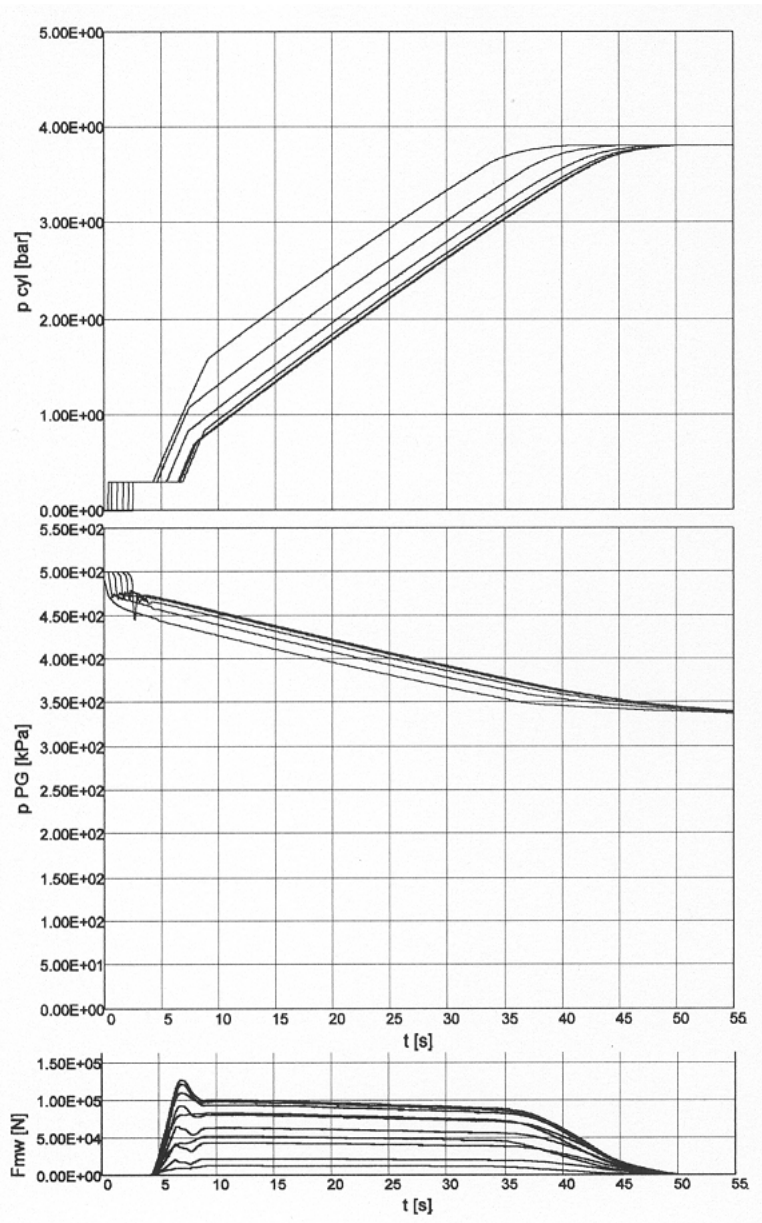

Rys. 6. Hamowanie służbowe pociąu 700 m:

a) nastawienie „osobowy”, b) nastawienie „towarowy”

\subsubsection{Zaskok}

Urządzenie zaskoku jest bardzo pożyteczne w trakcie hamowania w nastawieniu ,towarowy”. Winno ono mieć jak największą przepustowość, ale ograniczoną do niewielkiego wzrostu ciśnienia w cylindrze ( nominalnie przyjęto 0,35 bar). Zwiększenie ciśnienia zaskoku do wartości 0,7 bar (tabela 1, 1.p. 17) stosowane wcześniej spowodowałoby niewielkie zmniejszenie drogi hamowania pociagu, ale równocześnie wzrost sił wzdłużnych. W wartościach bezwzględnych wzrost nie jest duży, ale wzmocnił początkowe szybkie ich narastanie; dla rzeczywistych zderzaków podatnych powoduje to zwiększone szarpnięcia wewnątrz składu pociagu.

\subsubsection{Przyspieszacze początku hamowania}

Przyspieszacze te są niezbędne w nowoczesnych zaworach rozrządczych. Winny one zapewniać jak największy przepust powietrza ograniczony spadkiem ciśnienia w PG lub czasem. Bez przyspieszaczy proces hamowania długich pociagów byłby niepewny i spowolniony (rys. 7). W układzie bez przyspieszaczy rozpoczęcie hamowania nie jest dokładnie określone i zależy od dyszy napełniania zbiornika sterującego oraz od histerezy działania zaworu. Przedstawione $\mathrm{w}$ tabeli 1, 1.p. 15, 18, 20 i 22, wartości liczbowe sa tylko orientacyjne i leżą po stronie mniejszych dróg hamowania i mniejszych sił wzdłużnych. Są one również $\mathrm{z}$ tego powodu hipotetyczne, że wszystkie nowoczesne zawory rozrządcze posiadają przyspieszacze. Nieco tylko większy, niż założony dla „normalnego" zaworu rozrządczego przelot dyszy powodującej nieczułość zaworu rozrządczego powodowałby niezadziałanie hamulców w końcowej części długiego pociagu. Brak przyspieszaczy dla hamowań służbowych i długich pociagów jest niedopuszczalny. Mógłby powodować nieskuteczność działania hamulca i nawet dwukrotny wzrost sił wzdłużnych. 
a)
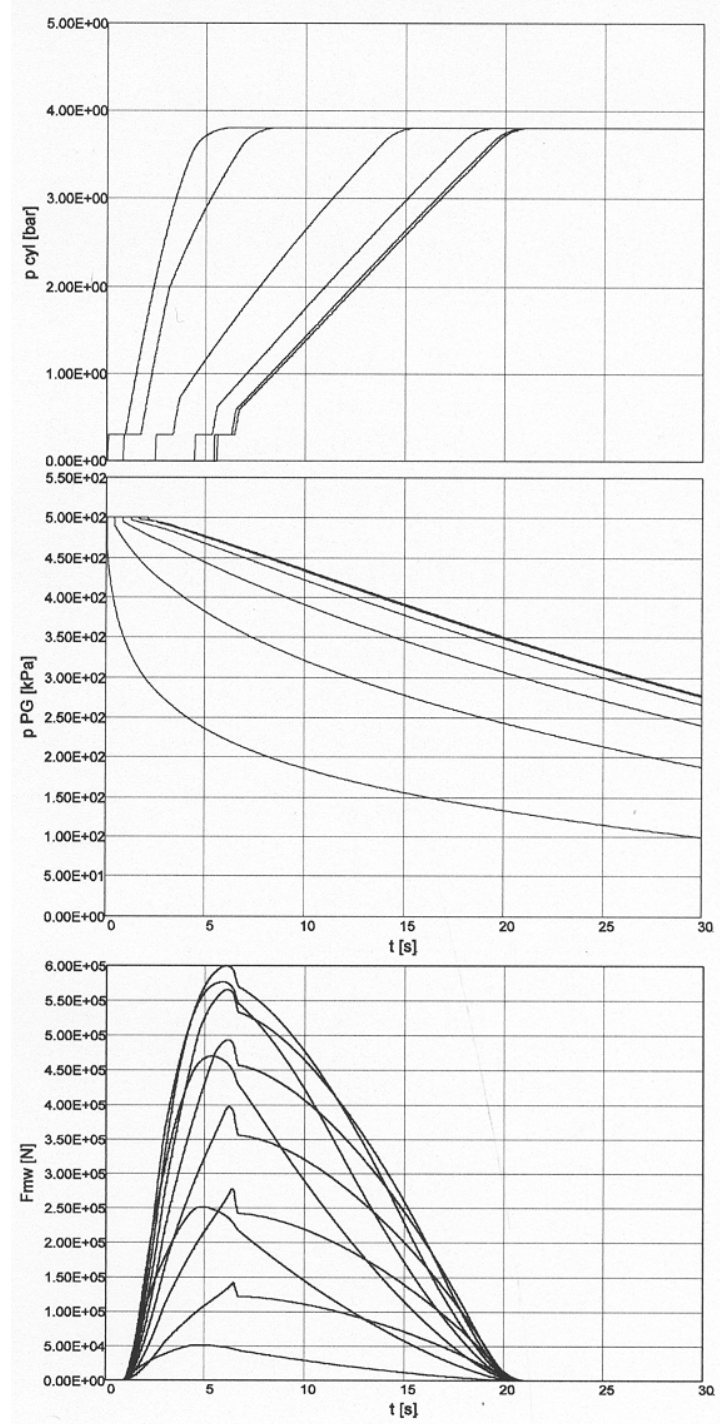

b)
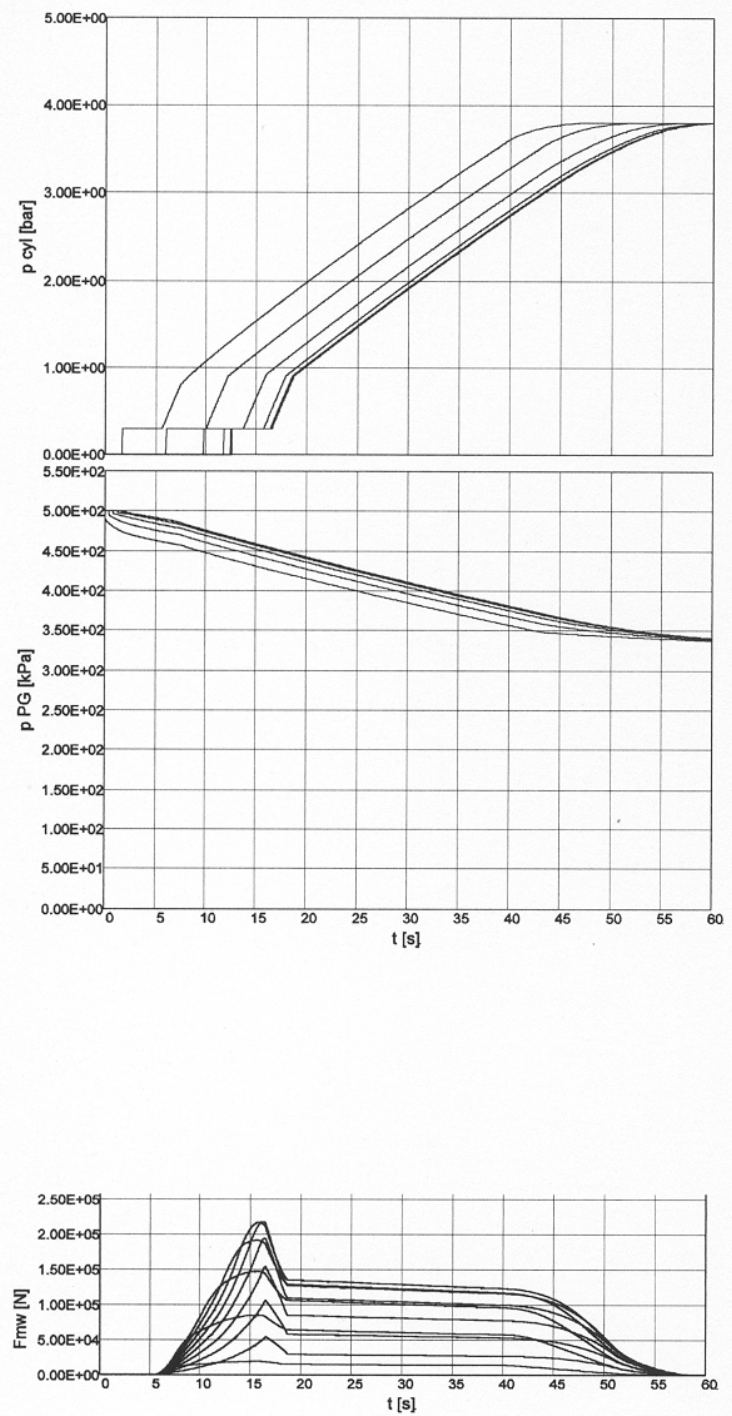

Rys 7. Hamowanie pociagu 700m, zawory rozrządcze bez przyspieszaczy: a) hamowanie nagłe, nastawienie „osobowy”, b) hamowanie służbowe, nastawienie ,towarowy”

\section{Podsumowanie}

Jak wynika $\mathrm{z}$ przeglądu doskonalenia aparatów hamulcowych, tylko dla niewielu parametrów można ogólnie wskazać ich wartości optymalne; dla większości parametrów wartości optymalne są związane z konkretną budową zaworu rozrządczego i dla takich przypadków bardzo przydatne mogą być przedstawione metody modelowania.

Przedstawiona metoda modelowania układu pneumatycznego hamulca posiada duże możliwości. Przy jej zastosowaniu można przeanalizować w wystarczającą dokładnością wpływ różnorodnych elementów budowy układu hamulcowego na hamowność pociagu i łagodny poziom sił wzdłużnych.

Przy rozpatrywaniu zmian poszczególnych parametrów układu pneumatycznego hamulca pociagu można zauważyć, że jest on w przybliżeniu zoptymalizowany $\mathrm{w}$ trakcie historii rozwoju kolejnictwa $\mathrm{z}$ uwzględnieniem różnych długości obecnie najdłuższych pociagów.
Artykuł nie daje gotowych wskazówek, który układ jest najlepszy, zwłaszcza, że analizuje hamowność pociagu w pewnym uproszczeniu (i jako odniesienie ,hamowanie nagłe” i nastawienie „osobowy”), ale stosując analizę wpływu umożliwia ocenę rezultatów polepszenia pracy układu hamulcowego poszczególnymi możliwymi technicznie rozwiązaniami.

\section{Literatura}

[1] Gasowski W., Piechowiak T.: Problemy przepływu powietrza $w$ uktadzie hamulcowym pociagu. Pojazdy Szynowe, Nr 1/2003.

[2] Gqsowski W., Piechowiak T.: Matematyczny opis zjawisk zachodzacych w uktadzie pneumatycznym hamulca pociagu. Pojazdy Szynowe, Nr 1/2004. 
[3] Gasowski W., Piechowiak T.: Simulation model of Train's Main Brake Conduit. Archiwum Transportu. Nr 1, 2008, zgloszony do druku.

[4] Grzesikiewicz W.: Badanie zjawisk dynamicznych $w$ pociagu ze sprzegami samoczynnymi. Rozprawa doktorska, Warszawa, 1975.

[5] Piechowiak T.: Wplyw wybranych parametrów układu hamulcowego na bezpieczeństwo jazdy pociagów towarowych. Rozprawa doktorska, Politechnika Poznańska, Poznań, 1985.

[6] Piechowiak T, Kaluba M.: Wplyw napetniania przewodu głównego wysokim ciśnieniem na proces luzowania pociagu. XIV Konf. Nauk. Pojazdy Szynowe 2000, Kraków 2000r.

[7] Piechowiak T.: Oddziatywanie przewodu głównego na prace zaworu maszynisty hamulca pociagu. Prace Naukowe Instytutu Konstrukcji i Eksploatacji Maszyn Politechniki Wroctawskiej. Wrocław 2002, XV Konferencja „Pojazdy Szynowe 2002".

[8] Piechowiak T.: Modelowanie uktadu mechanicznego $w$ urzadzeniach pneumatycznych hamulca. Pojazdy Szynowe, Nr 3-4/2004.
[9] Piechowiak T.: Metoda matematycznego modelowania uktadu pneumatycznego hamulca pojazdu szynowego. Pojazdy Szynowe, Nr 3/2005.

[10] Piechowiak T.: Metody modelowania pracy zaworów rozrzqdczych pojazdów szynowych. Pojazdy Szynowe, nr 1/2006.

[11] Piechowiak T.: Weryfikacja modeli symulacyjnych pneumatycznego hamulca kolejowego pomiarami doświadczalnymi. Zeszyty Naukowe Instytutu Pojazdów. Politechnika Warszawska, Nr 2(61)/2006.

[12] Piechowiak T.: Opory mechaniczne wystepujace $w$ cylindrze hamulcowym. Pojazdy Szynowe, $\mathrm{Nr}$ 3/2006.

[13] Piechowiak T.: Badanie i modelowanie procesów zachodzacych $w$ pneumatycznych uktadach hamulcowych pociagu. Politechnika Poznańska , Rozprawy, $\mathrm{Nr}$ 414, 2007 r.

[14] Norma PN-76/M-34034. Rurociagi. Zasady obliczeń strat ciśnienia. 